\title{
MATERNAL FACTORS ASSOCIATED WITH LOW BIRTH WEIGHT BABIES DELIVERED IN SELECTED PRIMARY HEALTH CARE CENTRES IN ABUJA MUNICIPAL AREA COUNCIL, FCT, NIGERIA
}

\author{
Adeosun Lydia Temidayo ${ }^{1}$, Amosu Ademola M. (Ph.D) ${ }^{2}$ \\ ${ }^{1}$ Department of Public Health, Babcock University, Ilishan-Remo, Ogun State, Nigeria. \\ Email: temsilee@gmail.com \\ ${ }^{2}$ Department of Public Health, Babcock University, Ilishan-Remo, Ogun State, Nigeria
}

Cite this article:

Adeosun L.T., Amosu A.M. (2021), Maternal Factors Associated with Low Birth Weight Babies Delivered in Selected Primary Health Care Centres in Abuja Municipal Area Council, FCT, Nigeria. African Journal of Health, Nursing and Midwifery 4(3), 121-138. DOI: 10.52589/AJHNMIZVHEFLX.

\section{Manuscript History}

Received: 16 May 2021

Accepted: 6 April 2021

Published: 20 June 2021

Copyright $\odot 2020$ The Author(s). This is an Open Access article distributed under the terms of Creative Commons Attribution-NonCommercialNoDerivatives 4.0 International (CC BY-NC-ND 4.0), which permits anyone to share, use, reproduce and redistribute in any medium, provided the original author and source are credited.
ABSTRACT: Introduction: Globally, low birth weight remains a public health challenge and is a major risk factor for infant mortality. Therefore, this study investigated the factors associated with low birth weight babies delivered in health facilities within Abuja, Nigeria. Methodology: Secondary data from January 2017 to December 2020 was extracted from 330 delivery records in ten (10) Primary Health Care centres to assess the determinants of low birth weight babies born in Abuja. Findings: The results showed that the mean age of mothers was $27.8 \pm 5.1$. Majority of the mothers (93.6\%) were between 16 and 35 years of age, $93.6 \%$ were married, $67 \%$ were Christians, $23.3 \%$ had no formal education, $31.5 \%$ were housewives and $75.8 \%$ lived in rural communities. The mean birth weight of babies was $3.05 \pm 0.55 \mathrm{~kg}$ and $20.3 \%$ of the babies had low birth weight compared to $79.7 \%$ with normal weights at birth. Maternal age, $p=0.02$; marital status, $p=0.02$; religion, $p=001$; occupation, $p=0.001$; and weight, $p=0.000$ were found to be significantly associated with having $L B W$ babies. Maternal obstetric characteristics such as birth spacing, $p=0.00$; haematocrit level, $p=0.001$; pregnancy termination, $p=0.001$; and medical conditions, $p=0.00$ were also significantly associated with birth weight. Conclusion: The study reported a high prevalence of low birth weight; it also revealed the protective effects of being married on $L B W$. However, being a housewife significantly increased the risk for having a low birth weight baby.

KEYWORDS: Factors, Health Facilities, Low Birth Weight, Prevalence. 
ISSN: 2689-9418

Volume 4, Issue 3, 2021 (pp. 121-138)

\section{INTRODUCTION}

Given its role in foetal health and wellbeing, birth weight (BW) has overtime caught global attention, mainly due to it being a strong predictor of the mental development, future physical growth and overall survival of a child (Dahlui, Azahar, Oche \& Aziz, 2016). It is such that infant weight at birth is reflective of maternal nutrition status before and during pregnancy and is significantly associated with mortality risk in the first year of life and, to an extent, with developmental issues during childhood and the risk of different diseases during adulthood (Louis et al., 2016).

The World Health Organization (WHO), has defined low birth weight (LBW) as a new-born having a birth weight of less than 2500 gram at birth (Teklehaimot, Hailu \& Assefa, 2014). Globally, LBW continues to pose a serious public health problem as it is associated with both short and long-term health consequences. Its high priority at the global level, is due to the fact that it is a significant determinant of infant morbidity, which contributes greatly to the overall burden of childhood mortality (Girma et al., 2019).

About $15 \%$ to $20 \%$ of all births worldwide are LBW, which equates to more than 20 million births per year, of which $95.6 \%$ occur in developing countries. Although, there seems to be a slight decline in the global prevalence, the difference in the incidence of LBW between developed and developing countries remains significant. It is such that the developed countries still have $7 \%$ occurrence, while the occurrence in developing countries is at 15\% (Dahlui, Azahar, Oche \& Aziz, 2016). At the regional level, an estimated 28\% of LBW occur in South Asia, 13\% in sub-Saharan Africa and 9\% in Latin America (World Health Organization, 2014).

In Nigeria, an estimated 5-6 million babies born each year have LBW. Furthermore, previous studies have reported the higher incidence of LBW in Maiduguri, Ogun and Jos at 16.9\%, $12.1 \%$ and $11.4 \%$ respectively (Dahlui, Azahar, Oche \& Aziz, 2016). Thus, infant mortality rate in Nigeria is still one of the highest in sub-Saharan Africa; at the global level, Nigeria had the second highest number of neonatal deaths in 2010 and also accounted for $9 \%$ of global neonatal deaths in 2016 (Olaniyi \& Ncama, 2019; Ogbuoji \& Yamey, 2019). Olaniyi \& Ncama (2019) noted that although lack of trained health professionals, income and difficulty in accessing healthcare, among others, have been listed as factors contributing to neonatal mortality, low birth weight has also been reported to be associated with new-born mortality. It is such that of the over 7 million babies born per year, 15\% are LBW (Project Concern International \& US Agency for International Development, 2015).

Given the global impact of LBW, several calls to action have been undertaken, one of which is the "A World Fit for Children", a declaration and action plan adopted by the United Nations that was launched in 2002, with the sole aim of reducing the incidence of LBW by at least one third between 2000 and 2010 (Teklehaimot, Hailu \& Assefa, 2014); it was a part of the Millennium Development Goal (MDG) to reduce child mortality by 2015 . Even more recently in 2012, a comprehensive implementation plan on maternal, infant and young child nutrition was endorsed by the World Health Assembly Resolution 65.6. The plan highlights six global nutrition targets for 2025, in which the third target focuses on a 30\% reduction in low birth weight (World Health Organization, 2014). Nonetheless, achieving this goal will require more than mere declarations alone. 
ISSN: 2689-9418

More than 5-6 million (17\%) babies are born with LBW in Nigeria, with nearly 100,000 resulting in fatality (Chidiebere et al., 2018). A study by Dahlui analysed data from the 2013 Nigeria Demographic and Health Survey and reported the prevalence of LBW to be $7.3 \%$. High incidences have been reported in states across the nation. For example, in Maiduguri, Takai, Bukar and Audu (2014) reported a high incidence (16.9\%) of LBW; in Lagos, the incidence was $10.2 \%$ (Olusanya \& Ofovwe, 2010), while an even higher incidence of LBW was reported in Kano at 32.1\% (951 babies), which was associated with increased neonatal morbidity and mortality rates (Muktar-Yola \& Iliyasu, 2007).

In the aforementioned studies conducted in Nigeria, low income and standard of living, marital status, maternal factors, anaemia, poor nutritional status of mothers at conception, short maternal height and lack of antenatal care were highlighted as risk factors for LBW. However, the prevalence of LBW reported in these studies may not be truly reflective of the magnitude of the challenge in Nigeria. Oladeinde, Oladeinde, Omoregie and Onifade (2015) highlighted this as a major concern, especially since traditional birth attendants (TBAs) deliver a majority of pregnant women, and data on BW of babies born in such centers is unaccounted for.

In the North Central region where Abuja is located, studies have reported the prevalence of LBW to be $30.5 \%$ in Benue (Ochogah, Abah, Idoko \& Dabit, 2018) and 16.9\% in Jos (Dahlui, Azahar, Oche \& Aziz, 2016).

Infants with LBW are usually disadvantaged and have a higher risk of neonatal and postneonatal mortality and morbidity. Furthermore, early and late morbid conditions such as coronary heart disease, impaired cognitive ability and psychological disorders are also associated with children within this category, which makes them a burden for both their families and particularly, the government in developing countries (Desta, 2019). In addition to this, LBW babies also suffer from perinatal-neonatal problems such as infections, malformation, asphyxia, hypothermia and neonatal sepsis (Bayih et al., 2019).

Despite the continuous global emphasis on primary health care and maternal and child health services, LBW remains a serious public health concern. Therefore, this retrospective study aims to determine the prevalence as well as the factors associated with low birth weight babies delivered in selected health facilities in Abuja.

\section{MATERIALS AND METHODS}

\section{Study area}

This study was carried out in Abuja, the Federal Capital Territory (FCT) of Nigeria, which comprises six council development areas namely: Abaji, Abuja municipal, Bwari, Gwagwalada, Kwali and Kuje. Abuja Municipal is the largest and the most developed of all six area councils within the FCT. It is situated between latitude $7^{\circ} 49^{\prime}$ and $8^{\circ} 49^{\prime}$ north of the equator and longitude $7^{\circ} 07^{\prime}$ and $7^{\circ} 33^{\prime}$ east of the Greenwich Meridian, and has a land mass of about 2,500 sq km. Abuja Municipal Area Council (AMAC) has both the highest and lowest elevation points, which differ significantly from each other. Abuja, the Federal Capital Territory (FCT) of Nigeria, comprises six council development areas namely: Abaji, Abuja municipal, Bwari, Gwagwalada, Kwali and Kuje. Abuja Municipal Area Council (AMAC) is the largest and the most developed of all six area councils within the FCT. It is situated between 
latitude $7^{\circ} 49^{\prime}$ and $8^{\circ} 49^{\prime}$ north of the equator and longitude $7^{\circ} 07^{\prime}$ and $7^{\circ} 33^{\prime}$ east of the Greenwich Meridian, and has a land mass of about 2,500 sq km. It comprises 53 Primary Health Care Centres, which are spread across 10 wards.

\section{Study design}

This was a retrospective study through the use of secondary analysis of available antenatal and delivery records in the selected health facilities, from January 2017 and December 2020. The prevalence and the determinants of low birth weight babies born in the selected health facilities within Abuja were assessed.

\section{Sampling size and sampling criteria}

The sample size was 330 and it included mothers who delivered at the selected health facilities from January 2017 to December 2020, and whose antenatal and delivery records are available in the health facilities' register. Mothers who delivered at the selected health facilities from January 2017 to December 2020 but whose antenatal and delivery records are incomplete (particularly where the outcome variable, birth weight, is missing) were excluded. In addition, all preterm deliveries were excluded from the study.

\section{Sampling technique}

Multistage sampling technique was employed to select the sample from the target population. Simple random sampling technique by means of balloting was used to select the ten (10) facilities that were included in the study. The facilities include Gosa, Gwagwa, Idu-Karimo, Kabusa, Karu, Kobi, Kuchigoro, Lugbe, Mabushi and Waru.

\section{Study instrument}

A structured Data Extraction Form was used to extract relevant information from the antenatal and delivery records of all the selected health facilities, based on the study objectives.

\section{Statistical analysis}

Secondary data analysis was done using version 23 IBM Statistical Package for the Social Sciences (SPSS). Prior to the data analysis, the age of each mother was recorded from discrete, quantitative variables to the ordinal variables as $16-25,26-35$ and $36-45$ years. The marital status of each mother was coded as nominal variables where $1=$ married, $2=$ divorced, $3=$ widowed and $4=$ single. The educational level of each mother was coded as ordinal variables as university/polytechnic, secondary, primary, others and none. Each mother's place of residence was coded as binary variables, either as rural or urban, where 1 is "rural" and 2 is "urban". Each mother's occupation was coded as ordinal variables as housewife, trader, farmer, civil servant and others. Each mother's height was recorded as normal stature $(155 \mathrm{~cm}$ and above) and short stature (154cm and below). The weight of each mother at 9 months was recorded from ratio variables to ordinal variables as $<70 \mathrm{~kg}$, and to reflect nutritional status. The gestational age was coded as ordinal variables as 39-42 weeks and $>42$ weeks. Each mother's parity was recorded from a discrete variable into a categorical variable as primiparous, multiparous and grand multiparous.

Birth spacing was coded as ordinal variables as not applicable (NA), $<18$ months, 18-36 months and > 36 months. Using the WHO cut-offs, the haematocrit level was recorded as 
ISSN: 2689-9418

ordinal variables, represented as follows: anaemia (Packed Cell Volume $<33 \%$ ) and normal haematocrit (Packed Cell Volume $\geq 33 \%$ ). Pregnancy termination/abortion was coded into nominal variables as yes and no. Medical conditions were coded as nominal variables as yes or no, based on the presence of any of the conditions or illnesses highlighted; 1 will be "yes" and 2 will be "no". The total number of antenatal visits by the mothers was recorded from discrete to ordinal variables as $0,1-4$ and $>4$ visits. Nutritional counselling was coded as a nominal variable, either as yes or no, where 1 is "yes" and 2 is "no". The dependent variable, $\mathrm{BW}$, was recorded from a continuous variable to a binary variable using $2500 \mathrm{~g}$ as the reference point. Therefore, babies who weighed $<2500 \mathrm{~g}$ at birth were coded as low birth weight while those that weighed $\geq 2500 \mathrm{~g}$ were coded as normal birth weight and above.

The demographic characteristics of the mothers were evaluated and presented in simple frequency tables and percentages. Chi squared test was used to test for an association between birth weight and maternal factors (maternal age, marital status, educational level, place of residence, occupation, place of ANC, maternal height, weight at 9 months, gestational age, parity, haematocrit level, pregnancy termination/abortion, medical conditions/illnesses, place of ANC, total number of ANC visits, and nutritional counselling). Subsequently, univariate binary logistic regression was used to determine the individual relationship between LBW and factors found to be significantly associated. A p-value of $\leq 0.05$ was considered significant. Lastly, frequency tables and percentages were used to determine the prevalence of LBW babies.

\section{Ethical Consideration}

Although there was no direct contact with the mothers, ethical clearance was obtained from the Babcock University Health Research Ethics Committee (BUHREC) and from the Abuja Municipal Area Council (AMAC). Data collected was anonymised to ensure the confidentiality of all women whose records were assessed.

\section{RESULTS}

\section{Socio-demographic characteristics of mothers}

Table 1 shows the background characteristics of the mothers and their babies. The mean weight of babies in kilogram $(\mathrm{kg})$ was $3.05 \pm 0.55$, ranging from $2.0-4.5 \mathrm{~kg}$. Less than half $(20.3 \%)$ of the babies had low birth weight (see Table 1). A total of 330 antenatal and delivery records of women with complete data in the health facilities were analysed in this study, and the mean age of women was 27.8 \pm 5.1 years. Most (59.4\%) of the women were between the ages of 26 and 35. Majority (93.6\%) of the women were married and most $(67 \%)$ of them were Christians. Less than a quarter $(23.3 \%)$ was Hausa. Less than half $(34.5 \%)$ of the women had secondary education. Many $(31.5 \%)$ of the women who delivered in the health facilities were full time housewives, while those who worked were mainly petty traders $(23.3 \%)$, farmers $(6.7 \%)$ and civil servants $(9.1 \%)$. Majority $(75.8 \%)$ of the women lived in rural areas.

Majority (93.3\%) of the women were of normal stature $(155 \mathrm{~cm}$ and above), while $6.7 \%$ were of short stature (154cm and below). More than half $(57.3 \%)$ of the women had normal weight. Majority (95.2\%) of the women were between 39-42 weeks of gestation. With respect to the parity of the women, $25.2 \%$ of the women were primiparous, $65.8 \%$ were multiparous, while 
African Journal of Health, Nursing and Midwifery

ISSN: 2689-9418

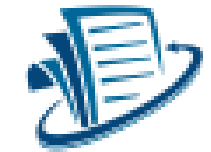

Volume 4, Issue 3, 2021 (pp. 121-138)

www.abjournals.org

9.1\% were grand multiparous. Less than half $(36.5 \%)$ of the women spaced their babies between 18-36 months. Assessment of the women's packed cell volume revealed that $37.6 \%$ were anaemic while $62.4 \%$ had a normal haematocrit level. Few $(6.4 \%)$ of the women had terminated their pregnancy with $66.7 \%$ of the pregnancy terminated before the sixth month. Less than half $(30.6 \%)$ of the women had medical conditions. The following were the medical conditions experienced by the women: hypertension (7.8\%), diabetes mellitus $(2.6 \%)$, HIV (17.5\%), tuberculosis (2.6\%), malaria (64.3\%) and pre-eclampsia (5.2\%) (see Table 2). Three hundred women were booked for antenatal care while 30 were not booked for antenatal care. Most (68.8\%) of the women visited the ANC between 1 and 4 times (see Figure 1). Majority (96.7\%) of the women had nutritional counselling (see Table 2).

Table 1: Background Characteristics of Mothers and Babies Delivered in the Selected Health Facilities

\begin{tabular}{|c|c|c|}
\hline Items & $\begin{array}{l}\text { Frequency } \\
(n=330)\end{array}$ & $\begin{array}{l}\text { Percent } \\
(\%)\end{array}$ \\
\hline \multicolumn{3}{|c|}{ Babies' Birth Weight (Mean weight of babies $(\mathrm{kg})=3.05 \pm 0.55$ ) } \\
\hline Normal birth weight ( $2.5 \mathrm{~kg}$ and above) & 263 & 79.7 \\
\hline Low birth weight (Less than $2.5 \mathrm{~kg}$ ) & 67 & 20.3 \\
\hline \multicolumn{3}{|l|}{ Age in years $($ mean age $=27.8 \pm 5.1)$} \\
\hline $16-25$ & 113 & 34.2 \\
\hline $26-35$ & 196 & 59.4 \\
\hline $36-45$ & 21 & 6.4 \\
\hline \multicolumn{3}{|l|}{ Marital Status } \\
\hline Married & 309 & 93.6 \\
\hline Divorced & 1 & 0.3 \\
\hline Single & 20 & 6.1 \\
\hline \multicolumn{3}{|l|}{ Religion } \\
\hline Islam & 109 & 33.0 \\
\hline Christianity & 221 & 67.0 \\
\hline \multicolumn{3}{|l|}{ Ethnicity } \\
\hline Hausa & 77 & 23.3 \\
\hline Igbo & 76 & 23.0 \\
\hline Yoruba & 45 & 13.6 \\
\hline Others & 132 & 40.0 \\
\hline \multicolumn{3}{|l|}{ Educational level } \\
\hline University/polytechnic & 101 & 30.6 \\
\hline Secondary & 114 & 34.5 \\
\hline Primary & 38 & 11.5 \\
\hline No formal education & 77 & 23.3 \\
\hline \multicolumn{3}{|l|}{ Occupation } \\
\hline Housewife & 104 & 31.5 \\
\hline Trader & 77 & 23.3 \\
\hline Farmer & 22 & 6.7 \\
\hline Civil servants & 30 & 9.1 \\
\hline *Others & 97 & 29.4 \\
\hline \multicolumn{3}{|l|}{ Place of Residence } \\
\hline Rural & 250 & 75.8 \\
\hline Urban & 80 & 24.2 \\
\hline
\end{tabular}

*Tailor, students, cleaners, realtor, hair stylist and salesgirls 
African Journal of Health, Nursing and Midwifery

ISSN: 2689-9418

Volume 4, Issue 3, 2021 (pp. 121-138)

Table 2: Obstetric Characteristics of Mothers

\begin{tabular}{|c|c|c|}
\hline Items & $\operatorname{Frequency}(n=330)$ & Percent (\%) \\
\hline \multicolumn{3}{|l|}{ Height(m) } \\
\hline$\leq 1.54$ (Short stature) & 22 & 6.7 \\
\hline$\geq 155$ (Normal stature) & 308 & 93.3 \\
\hline \multicolumn{3}{|l|}{ Weight(kg) } \\
\hline$<70$ & 141 & 42.7 \\
\hline$>70$ & 189 & 57.3 \\
\hline \multicolumn{3}{|l|}{ Parity } \\
\hline Primiparous & 83 & 25.2 \\
\hline Multiparous & 217 & 65.8 \\
\hline Grand multiparous & 30 & 9.1 \\
\hline \multicolumn{3}{|l|}{ Birth Spacing } \\
\hline$<18$ months & 160 & 48.4 \\
\hline 18-36 months & 120 & 36.4 \\
\hline$>36$ months & 50 & 15.2 \\
\hline \multicolumn{3}{|l|}{ Hematocrit level } \\
\hline$<33 \%$ (Anaemia) & 124 & 37.6 \\
\hline$\geq 33 \%$ (Normal) & 206 & 62.4 \\
\hline \multicolumn{3}{|c|}{ Pregnancy Termination/Abortion } \\
\hline Yes & 21 & 6.4 \\
\hline No & 309 & 93.6 \\
\hline \multicolumn{3}{|l|}{ Pregnancy termination time* } \\
\hline$<6$ months before pregnancy & 14 & 66.7 \\
\hline$>6$ months before pregnancy & 7 & 33.3 \\
\hline \multicolumn{3}{|l|}{ Medical condition/Illness } \\
\hline Yes & 115 & 34.8 \\
\hline No & 215 & 65.2 \\
\hline \multicolumn{3}{|c|}{ Types of Medical conditions experienced $* *$} \\
\hline Hypertension & 9 & 7.8 \\
\hline Diabetic mellitus & 3 & 2.6 \\
\hline HIV & 20 & 17.5 \\
\hline Tuberculosis & 3 & 2.6 \\
\hline Malaria & 74 & 64.3 \\
\hline Pre-eclampsia & 6 & 5.2 \\
\hline \multicolumn{3}{|l|}{ Nutritional counselling } \\
\hline Yes & 319 & 96.7 \\
\hline No & 11 & 3.3 \\
\hline
\end{tabular}

$* \mathrm{n}=21 ; * * \mathrm{n}=115$ 


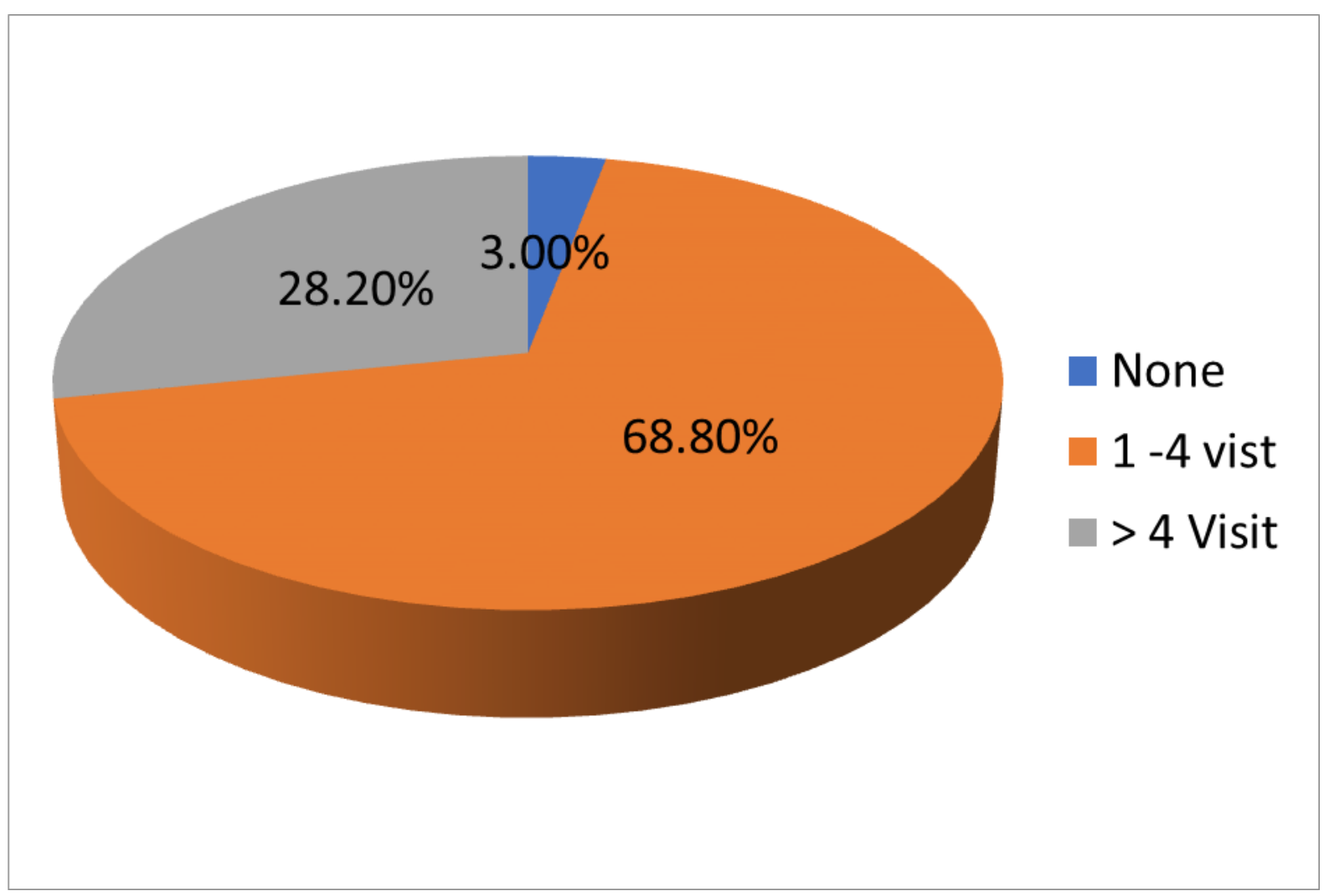

Figure 1: Mothers' Antenatal Care Visits

\section{Association between maternal factors and birth weight}

Table 3 and Table 4 showed the association between maternal demographic factors and baby's birth weight, and maternal obstetric factors and baby's weight respectively. Result showed that maternal age $\left(X^{2}=7.41 ; p=0.02\right)$, marital status $\left(X^{2}=8.24 ; p=0.02\right)$, religion $\left(X^{2}=6.66 ; p=0.01\right)$, occupation $\left(X^{2}=19.38 ; p=0.001\right)$, weight $\left(X^{2}=49.3 ; p=0.00\right)$, birth spacing $\left(X^{2}=723.4 ; p=0.00\right)$, haematocrit level $\left(X^{2}=11.2 ; p=0.001\right)$, termination of pregnancy $\left(X^{2}=14.3 ; p=0.001\right)$, antenatal visit $\left(X^{2}=19.6 ; p=0.00\right)$, nutritional counselling $\left(X^{2}=19.3 ; p=0.00\right)$, and medical condition $\left(\mathrm{X}^{2}=30.2 ; \mathrm{p}=0.00\right)$ were significantly associated with the birth weight of babies. However, maternal ethnicity $\left(X^{2}=4.75 ; p=0.19\right)$, educational level $\left(X^{2}=6.37 ; p=0.09\right)$, place of residence $\left(\mathrm{X}^{2}=2.80 ; \mathrm{p}=0.11\right)$, height $\left(\mathrm{X}^{2}=0.06 ; \mathrm{p}=0.52\right)$ and parity $\left(\mathrm{X}^{2}=5.82 ; \mathrm{p}=0.05\right)$ were not significantly associated with the birth weight of babies. 
African Journal of Health, Nursing and Midwifery

ISSN: 2689-9418

Volume 4, Issue 3, 2021 (pp. 121-138)

www.abjournals.org

Table 3: Association Between Maternal Demographic Characteristics and Baby's Birth Weight

\begin{tabular}{|c|c|c|c|c|}
\hline Variables & $\begin{array}{l}\text { Normal } \\
\text { birth weight }\end{array}$ & $\begin{array}{l}\text { Low birth } \\
\text { weight }\end{array}$ & $\mathbf{X}^{2}$ & P-value \\
\hline Age in years & & & 7.41 & 0.02 \\
\hline $16-25$ & $82(24.8)$ & $31(9.4)$ & & \\
\hline $26-35$ & $161(48.8)$ & $35(10.6)$ & & \\
\hline $36-45$ & $20(6.1)$ & $1(0.3)$ & & \\
\hline Marital Status & & & 8.24 & 0.02 \\
\hline Married & $251(76.1)$ & $58(17.6)$ & & \\
\hline Divorced & $1(0.3)$ & $0(0.0)$ & & \\
\hline Single & $11(3.3)$ & $9(2.7)$ & & \\
\hline Religion & & & 6.66 & 0.01 \\
\hline Islam & $78(23.6)$ & $31(9.4)$ & & \\
\hline Christianity & $185(56.1)$ & $36(10.9)$ & & \\
\hline Ethnicity & & & 4.75 & 0.19 \\
\hline Hausa & $56(17.0)$ & $21(6.4)$ & & \\
\hline Igbo & $65(19.7)$ & $11(3.3)$ & & \\
\hline Yoruba & $34(10.3)$ & $11(3.3)$ & & \\
\hline Others & $108(32.7)$ & $24(7.3)$ & & \\
\hline Educational Level & & & 6.37 & 0.09 \\
\hline University/polytechnic & $85(25.8)$ & $15(4.5)$ & & \\
\hline Secondary & $90(27.3)$ & $24(7.3)$ & & \\
\hline Primary & $25(7.6)$ & $13(3.9)$ & & \\
\hline No formal education & $63(19.1)$ & $15(4.5)$ & & \\
\hline Occupation & & & 19.38 & 0.001 \\
\hline Housewife & $69(20.9)$ & $35(10.6)$ & & \\
\hline Trader & $68(20.6)$ & $9(2.7)$ & & \\
\hline Farmer & $17(5.2)$ & $5(1.5)$ & & \\
\hline Civil servant & $28(8.5)$ & $2(0.6)$ & & \\
\hline Others & $81(24.5)$ & $16(4.8)$ & & \\
\hline Place of Residence & & & 2.80 & 0.11 \\
\hline Rural & $194(58.8)$ & $56(17.0)$ & & \\
\hline Urban & $69(20.9)$ & $11(3.3)$ & & \\
\hline
\end{tabular}


African Journal of Health, Nursing and Midwifery

ISSN: 2689-9418

Volume 4, Issue 3, 2021 (pp. 121-138)

www.abjournals.org

Table 4: Association Between Maternal Obstetric Characteristics and Baby's Birth Weight

\begin{tabular}{|c|c|c|c|c|}
\hline Variable & $\begin{array}{l}\text { Normal birth } \\
\text { weight } \\
\text { N (\%) }\end{array}$ & $\begin{array}{l}\text { Low birth } \\
\text { weight } \\
\text { N }(\%)\end{array}$ & $\mathbf{X}^{2}$ & P-value \\
\hline Maternal height & & & 0.06 & 0.52 \\
\hline Normal stature & $245(74.2)$ & $4(1.2)$ & & \\
\hline Short stature & $18(5.50$ & $63(19.1)$ & & \\
\hline Weight(kg) & & & 49.26 & 0.000 \\
\hline$<70$ & $87(26.4)$ & $54(16.4)$ & & \\
\hline$>70$ & $176(53.5)$ & $13(3.9)$ & & \\
\hline$<18$ months & $52(15.8)$ & 26(7.9) & & \\
\hline 18-36 months & $108(32.7)$ & $12(3.6)$ & & \\
\hline$>36$ months & $45(13.6)$ & $5(1.5)$ & & \\
\hline Haematocrit Level & & & 11.2 & 0.001 \\
\hline Anaemia & $87(26.4)$ & $37(11.2)$ & & \\
\hline Normal & $176(53.3)$ & $30(9.1)$ & & \\
\hline Termination of Pregnancy & & & 14.3 & 0.001 \\
\hline Yes & $10(3.0)$ & $11(3.3)$ & & \\
\hline No & $253(76.7)$ & $56(17.0)$ & & \\
\hline Antenatal care Visit & & & 19.6 & 0.00 \\
\hline None & $3(0.9)$ & $7(2.1)$ & & \\
\hline $1-4$ & $178(53.9)$ & $49(14.8)$ & & \\
\hline$>4$ & $82(24.8)$ & $11(3.3)$ & & \\
\hline Nutritional Counselling & & & 19.3 & 0.00 \\
\hline Yes & $260(78.8)$ & $59(17.9)$ & & \\
\hline No & $3(0.9)$ & $8(2.4)$ & & \\
\hline Medical condition & & & 30.2 & 0.00 \\
\hline Yes & $62(18.8)$ & $39(11.8)$ & & \\
\hline No & $201(60.9)$ & $28(8.5)$ & & \\
\hline
\end{tabular}

\section{Logistics Regression}

All variables that were significant in the chi square analysis at $p<0.05$ were entered into the logistic regression model to test for the association with birth weight.

Table 5 showed that maternal age was significantly associated with low birth weight. When compared with mother's age 36-45 years, mother's age 16-25years $(\mathrm{OR}=7.56$; $\mathrm{CI}=0.97-58.8$; $\mathrm{p}=0.04)$, and mothers age 26-35 years $(\mathrm{OR}=4.34 ; \mathrm{Cl}=0.56-33.5 ; \mathrm{p}=0.05)$ had higher odds of giving birth to LBW babies. Mothers who were married had lower odds of giving birth to LBW babies as compared with mothers who were single ( $\mathrm{OR}=3.54 ; \mathrm{CI}=1.40-8.93 ; \mathrm{p}=0.007)$. Mothers who were Muslims had lower odds of giving birth to higher birth weight babies as compared with mothers who were Christians ( $\mathrm{OR}=0.49$; $\mathrm{CI}=0.28-0.84 ; \mathrm{p}=0.01)$. Maternal occupation was significantly associated with having low birth weight babies; mothers who were housewives had higher odds of giving birth to low weight babies as compared with mothers who were traders $(\mathrm{OR}=0.26 ; \mathrm{CI}=0.11-0.58 ; \mathrm{p}=0.001)$ and civil servants $(\mathrm{OR}=0.14$; $\mathrm{CI}=0.03-0.62 ; \mathrm{p}=0.10)$. 
African Journal of Health, Nursing and Midwifery

ISSN: 2689-9418

Volume 4, Issue 3, 2021 (pp. 121-138)

www.abjournals.org

Mothers who were underweight had higher odds of having low birth weight babies ( $O R=8.40$; $\mathrm{CI}=4.35-16.22 ; \mathrm{p}=0.000$ ). Mothers who spaced their babies for more than 36 months were significantly associated with having lower odds of giving birth to low weight babies as compared to mothers who did not space their birth $(\mathrm{OR}=3.72 ; \mathrm{CI}=1.31-10.52 ; \mathrm{p}=0.01)$. When compared with non-anaemic mothers, mothers with anaemia $(\mathrm{OR}=2.49 \mathrm{CI}=1.44-4.30 \mathrm{p}=0.001)$ had higher odds for giving birth to LBW. Mothers who had terminated pregnancy had high odds of giving birth to low birth weight babies compared with mothers who had not $(\mathrm{OR}=0.40$; $\mathrm{CI}=0.23-0.69 ; \mathrm{p}=0.001)$. When compared with those who visited the antenatal clinic, mothers who did not attend the antenatal care clinic had higher odds of giving birth to low birth weight babies (OR=17.39; $\mathrm{CI}=3.91-77.3)$ (see Table 5).

Furthermore, mothers who had medical conditions during pregnancy had higher odds of giving birth to low birth weight babies $(\mathrm{OR}=4.51 ; \mathrm{CI}=2.57-7.92 ; \mathrm{p}=0.000)$. Similarly, mothers who did not receive nutritional counselling had higher odds of having low birth weight babies $(\mathrm{OR}=11.75 ; \mathrm{CI}=3.02-45.6 ; \mathrm{p}=0.000)$ (see Table 5).

Table 5: Logistic Regression of Maternal Factors Associated with Low Birth Weight

\begin{tabular}{|c|c|c|c|c|c|c|c|}
\hline Characteristics & B & $\begin{array}{l}\text { S.E } \\
\end{array}$ & Wald & df & $\operatorname{Exp}(B)$ & $\begin{array}{l}\text { 95\% Cl of } \\
\operatorname{Exp}(B)\end{array}$ & p-value \\
\hline \multicolumn{8}{|l|}{ Age in years } \\
\hline $16-25$ & 2.02 & 1.02 & 3.73 & 1 & 7.56 & 0.97 to 58.75 & 0.04 \\
\hline $26-35$ & 1.47 & 1.04 & 1.99 & 1 & 4.34 & 0.56 to 33.48 & 0.05 \\
\hline \multicolumn{8}{|l|}{$36-45$ (ref) } \\
\hline \multicolumn{8}{|l|}{ Marital Status } \\
\hline \multicolumn{8}{|l|}{ Married (ref) } \\
\hline Divorced & -19.3 & $\begin{array}{l}40192 . \\
9\end{array}$ & 7.16 & 1 & 0.00 & 0.00 & 1.00 \\
\hline \multirow{2}{*}{\multicolumn{8}{|c|}{ Religion }} \\
\hline & & & & & & & \\
\hline Christianity & 0.74 & 0.28 & 6.52 & 1 & 0.49 & 0.28 to 0.84 & 0.01 \\
\hline \multicolumn{8}{|l|}{ Occupation } \\
\hline \multicolumn{8}{|l|}{ Housewife (ref) } \\
\hline Trader & -1.34 & 0.41 & 10.68 & 1 & 0.26 & 0.11 to 0.58 & 0.001 \\
\hline Farmer & -0.54 & 0.54 & 0.98 & 1 & 0.38 & 0.19 to 0.70 & 0.03 \\
\hline Civil servant & -1.96 & 0.76 & 6.63 & 1 & 0.14 & 0.03 to 0.62 & 0.10 \\
\hline Others & 0.94 & 0.34 & 7.54 & 1 & 0.38 & 0.19 to 0.76 & 0.006 \\
\hline \multicolumn{8}{|l|}{ Maternal weight } \\
\hline \multicolumn{8}{|c|}{ Normal weight (ref) } \\
\hline Underweight & 2.21 & 0.33 & 40.23 & 1 & 8.40 & 4.35 to 16.22 & 0.00 \\
\hline \multicolumn{8}{|l|}{ Birth spacing } \\
\hline None & 1.35 & 0.53 & 6.14 & 1 & 3.72 & 1.31 to 10.52 & 0.01 \\
\hline$<18$ months & 0.18 & 0.34 & 0.30 & 1 & 3.72 & 0.61 to 2.36 & 0.57 \\
\hline $18-36$ months & 1.31 & 0.38 & 11.41 & 1 & 0.26 & 1.12 to 0.57 & 0.001 \\
\hline$>36$ months(ref) & & & & & & & \\
\hline
\end{tabular}


African Journal of Health, Nursing and Midwifery

ISSN: 2689-9418

Volume 4, Issue 3, 2021 (pp. 121-138)

www.abjournals.org

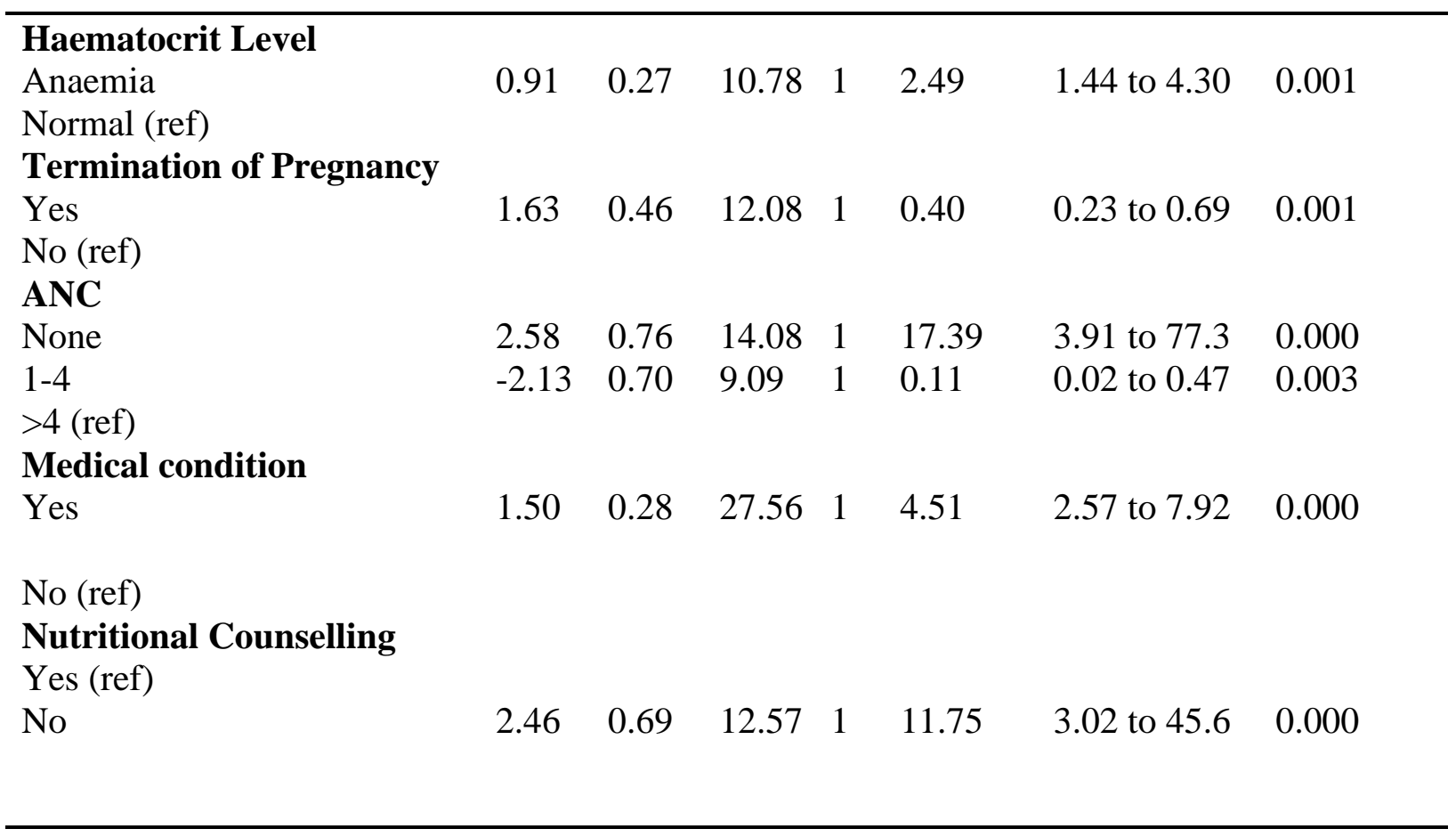

Ref-Indicates Reference Category.

\section{DISCUSSION}

In the present study, the mean birth weight of babies was $3.05 \pm 0.55$ with $20.3 \%$ of the babies having low birth weight. The mean weight of the babies was similar to that of a study conducted by Chingle et al. (2017) in Jos. However, the prevalence of LBW in this study was higher than that reported by Chingle et al. (2017) in Jos and lower than the prevalence reported by Muchemi, Echoka and Makokha (2015) in Kenya. The difference in findings may be due to regional variation. Also, the prevalence of LBW babies in these primary health care facilities could be attributed to the fact that they are mostly located in the rural areas within Abuja.

The findings in this study show that most of the women who gave birth at the PHCs were within the 26-35 years age group, which is the recommended reproductive age group. This was consistent with the findings of Zeleke, Zelalem and Mohammed (2012); Ugboma \& Onyearugha (2013) and Muchemi, Echoka, \& Makokha (2015). The proportion of LBW babies was higher among younger mothers compared to other age groups. These findings were similar to those in the study conducted in Ibadan by Amosu et al. (2011); Jayant et al. (2011) in India, and Maznah, Nazar, Oche, and Norlaili (2016) in Nigeria. Pregnancy at a young age is detrimental to the health of both the mother and the unborn child and in teenage mothers, the physical development of the girl is still not complete (Maznah, Nazar, Oche \& Norlaili, 2016).

This study also showed that parity is not significantly associated with the risk of delivering a LBW baby; however, the proportion of LBW babies was higher in multiparous women (10.9\%) than in primiparous women $(7.3 \%)$. Studies had reported that being a primiparous woman is one of the risk factors for LBW (Maznah, Nazar, Oche \& Norlaili, 2016; Chingle et al., 2017). Majority of the mothers were of rural residence. This was expected as it was predominantly a rural setting. From the sampled records, most women had completed secondary education. This 
ISSN: 2689-9418

was similar with the findings by Zeleke, Zelalem and Mohammed (2012). The proportion of LBW babies in the rural areas was higher than that of the urban areas in this study. It could be due to the fact that rural women are more exposed to poor diet, infections during pregnancy, and inadequate ANC facilities (Jayant, Phalke, Bangal, Peeyuusha \& Sushen, 2011).

The antenatal and delivery records showed that the women were mostly married, which is similar to findings of Chingle et al. (2017) and Muchemi, Echoka and Makokha (2015). Being married was significantly associated with low prevalence of LBW babies; this is in line with the findings of Siza (2008). The outcomes of this study indicated that maternal occupation is associated with having LBW. Being a housewife was found to increase the likelihood of women having LBW babies. These findings are similar to the reports of Tsimbos and Georgia (2011) in Greece and de Moraes (2012) in Brazil. The housewives being at risk of having low birth weight babies may be due to socio-economic dependency on their husbands, who are solely responsible for the income in the home. This influences the type of diet they can afford and their living conditions. However, the findings are at variance with the findings of Chingle et al. (2017) in Jos and Ugboma and Onyearugha (2013).

Maternal anaemia was significantly associated with LBW; this finding is consistent with studies from other countries (Borah \& Agarwalla, 2016; Yi, Han \& Ohrr, 2013). Majority of the women were from rural areas, a community that is often characterized by poverty and poor diet. Iron deficiency is reported as the most common cause of anaemia during pregnancy (Abdullahi, Gasim, Saeed, Imam \& Adam, 2014; Lawrence, 2010) and routine multiple micronutrient supplements are often prescribed. The higher risks of giving birth to LBW neonates by mothers who are anaemic, reflect the positive role a diet rich in iron plays during the period of pregnancy.

Mothers who spaced the birth of their pregnancy had lower odds of giving birth to LBW babies. This is similar to the findings of Chen et al. (2015); Cofer et al. (2016); Demelash, Motbainor, Nigatu, Gashaw and Melese (2015); Mahande and Obure (2016); Ugboma and Onyearugha (2013); and Wendt, Gibbs, Peters and Hogue (2012) where short and long inter-pregnancy intervals were linked to adverse pregnancy outcomes, including LBW. These findings suggest that pregnancies spread apart enable maternal recovery and, in turn, facilitate optimal foetal development. This study also identified that maternal weight was significantly associated with LBW; this finding is similar to the reports of Agarwal et al. (2011). This study revealed that mothers with weight less than $70 \mathrm{~kg}$ were eight times at risk of delivering LBW babies. It has been proven that maternal weight is one of the significant risk factors for LBW (Agarwal et al., 2011), underscoring the need to improve the nutritional status of women, especially during adolescence, in order to ensure that they have ideal weights.

The frequency of ANC visits were significantly associated with the birth weights of the infants. Similar findings were observed by various other studies that showed the risk of LBW was lower among those who had four or more ANC visits, in comparison to mothers who had less than four ANC visits (Agarwal et al., 2011; Chingle et al., 2017). The majority of the LBW infants were born to mothers who were late for their ANC registration. Inadequate ANC increases the risk of delivering LBW infants (Mumbare et al., 2012). The findings from this study revealed that maternal height was not significant with the risk of delivering LBW. This is not consistent with the findings of Amosu et al. (2011) and Jayant et al. (2011), where maternal height was a significant risk factor for the delivery of LBW. 
ISSN: 2689-9418

Volume 4, Issue 3, 2021 (pp. 121-138)

www.abjournals.org

This study showed that the odds of delivering low birth weight newborns among mothers who did not get nutritional counselling during ANC were three times higher than in women who received nutritional counselling. Providing antenatal care and nutritional counselling to pregnant women is effective in increasing their dietary intake that is geared towards ensuring a successful pregnancy and healthier pregnancy outcomes (Mulatu, Zepre \& Hailemicael, 2016; Betew \& Muluneh, 2014). Similarly, regular prenatal nutrition counselling increases maternal weight gain and increases birth weight of the newborns (Acter et al., 2012).

The odds of delivering low birth weight newborns among mothers with complications during pregnancy were two times higher than their counterparts. Previous studies also identified the presence of HIV infection, eclampsia/preeclampsia, and anaemia to be significantly associated with low birth weight as these predispose the foetus to intrauterine growth restrictions (Zenebe, Awoke \& Birhan, 2014; Demelash et al., 2015; Monjezi, Rostami, Moradi \& Cheraghian, 2014). It is known that any disorder that affects foetal nutritional gain during intrauterine life directly affects birth weight.

\section{Limitation of the Study}

This study was conducted with secondary data and being a health facility-based study, it does not assess the true practice of the health facilities' catchment area since the residents have a bias for home delivery, which is not accounted for in the study.

\section{CONCLUSION}

Maternal age, marital status, maternal occupation, birth spacing, maternal weight, and haematocrit level were the significant factors for LBW in Abuja. The prevalence of low birth weight in this study is high; however, the study revealed the protective effects of being married on low birth weight. Being a housewife significantly increased the risk for having a low birth weight baby. Even though LBW is influenced by a multiplicity of factors, the incidence of LBW could be reversed if maternal risk factors are detected earlier and appropriate prevention strategies are delivered to the high-risk group. From a public health perspective, it is an advantage that most of these factors can be modified. Improvement in the ANC services in Abuja is needed. Multi-faceted approaches could deliver better services to the pregnant mothers in Abuja. Such approaches would include health education, maternal nutrition, improvement in socio-economic indices, and more and better-quality ANC services.

\section{REFERENCES}

Abdullahi, H., Gasim, G. I., Saeed, A., Imam, A. M., \& Adam, I. (2014). Antenatal iron and folic acid supplementation use by pregnant women in Khartoum, Sudan. BMC Research Notes, 7, 498. doi:10.1186/1756-0500-7-498

Acter, S., Roy S., Sultana, M., Khatun, W., \& Rahman, R. (2012). Effects of Third Trimester Counseling on Pregnancy Weight Gain, Birth Weight and Breastfeeding among Urban Poor Women in Bangladesh. Food nutrition Bulletin, 33(3),194-201. 
ISSN: 2689-9418

Volume 4, Issue 3, 2021 (pp. 121-138)

www.abjournals.org

Agarwal, K., Agarwal, A., Agrawal, V. K., Agrawal, P., \& Chaudhary, V. (2011). Prevalence and Determinants of "Low Birth Weight" among Institutional Deliveries. Annals of Nigerian Medicine, 5(2), 48-52. https://doi.org/10.4103/0331-3131.92950

Alhassan, M.M., \& Ujoh, F. (2012). Assessment of the Chemical Quality of Potable Water Sources in Abuja, Nigeria. British Journal of Applied Science \& Technology 2(2), 146-172.

Amosu, A., Atulomah, N., Olanrewaju, M., Akintubde, T., Babalola, A., Akinnuga, A. (2011). Retrospective study of some factors influencing delivery of low birth weight babies in Ibadan, Oyo state, Nigeria. Science Research Essays, 6 (2), 236-240.

Bayih, W.A., Assefa, N., Dheresa, M., Minuye, B., \& Demis, S. (2019). Neonatal Hypothermia and Associated Factors Within Six Hours of Delivery in Eastern Part of Ethiopia: A cross-sectional study. BMC Pediatrics, 19(1), 252. https://doi.org/10.1186/s12887-019-1632-2

Betew, W., \& Muluneh, E. (2014). Determinants of Low Birth Weight among Children Aged 0 to 59 Months in Ethiopia. International Journal of Pure and Applied Sciences and Technology,25(1),14-25.

Borah, M., \& Agarwalla, R. (2016). Maternal and Socio-demographic Determinants of Low Birth Weight (LBW): A community-based study in a rural block of Assam. Journal of Postgraduate Medicine, 62(3), 178-181. https://doi.org/10.4103/0022-3859.184275

Chen, I., Jhangri, G. S., Lacasse, M., Kumar, M., \& Chandra, S. (2015). Obstetrics: Relationship Between Interpregnancy Interval and Adverse Perinatal and Neonatal Outcomes in Northern Alberta. Journal of Obstetrics and Gynaecology Canada, 37(7), 598-605. https://doi.org/10.1016/S1701-2163(15)30197-3

Chidiebere, O.D., Uchenna, E., Ikenna, N., Christian, I., Nwabueze A., Amadi, O., Stephen, A.O., \& Ifeyinwa, O. (2018). The Low-birth Weight Infants: Pattern of morbidity and mortality in a tertiary healthcare facility in the South Eastern Nigeria. Annals of Medical \& Health Sciences Research, 8:4-10.

Chingle, M.P., Bupwatda, P., Afolaranmi, T., Odunze, P., Dami, N., Yiltok, E., Yilgwan, C., Daboer, J.C., Ogbonna, C., Zoakah, A. (2017). Factors Associated with Low Birth Weight Babies Delivered in Comprehensive Health Centre, Gindiri, North Central Nigeria. Journal of Medical Science and Clinical Research,5(5), 22355-22366. https://dx.doi.org/10.18535/jmscr/v5i5.176

Cofer, F., Fridman, M., Lawton, E., Korst, L., Nicholas, L., \& Gregory, K. (2016). Interpregnancy Interval and Childbirth Outcomes in California, 2007-2009. Maternal \& Child Health Journal, 20(Suppl 1), 43-51. doi:10.1007/s10995-016-2180-0

Dahlui, M., Azahar, N., Oche, O.M., \& Aziz, N.A. (2016). Risk Factors for Low Birth Weight in Nigeria: Evidence from the 2013 Nigeria Demographic and Health Survey. Global Health Action, 9(1), 28822. https://dx.doi.org/10.3402\%2Fgha.v9.28822

de Moraes A., Zanini, R., Riboldi, J., \& Giugliani J. (2012). Risk factors for Low Birth Weight in Rio Grande do Sul State, Brazil: Classical and multilevel analysis. Cad. SaúdePública, 28(12), 2293-2305. doi.org/10.1590/S0102-311X2012001400008.

Demelash, H., Motbainor, A., Nigatu, D., Gashaw, K., \& Melese, A. (2015). Risk Factors for Low Birth Weight in Bale Zone Hospitals, South-East Ethiopia: A case-control study. BMC Pregnancy and Childbirth, 15(1), 1-10. https://doi.org/10.1186/s12884015-0677-y

Desta, M. (2019). Low Birth Weight and Adverse Perinatal Outcomes. In Childbirth. IntechOpen. http://dx.doi.org/10.5772/intechopen.89049 
ISSN: 2689-9418

Volume 4, Issue 3, 2021 (pp. 121-138)

www.abjournals.org

Girma, S., Fikadu, T., Agdew, E., Haftu, D., Gedamu, G., Dewana, Z \& Getachew, B. (2019). Factors Associated with Low Birthweight among Newborns Delivered at Public Health Facilities of Nekemte Town, West Ethiopia: A case control study. BMC Pregnancy and Childbirth, 19(1), 220. https://doi.org/10.1186/s12884-0192372-x

Jayant, D., Phalke, D., Bangal, V., Peeyuusha, D., Sushen, B (2011). Maternal Risk Factors for Low Birth Weight Neonates: A hospital-based case-control study in rural area of Western Maharashtra, India. National Journal of Community Medicine, 2, 3948.

Lawrence, P. (2010). Iron deficiency in pregnancy. Obstetric Medicine, 3, 17-24.

Louis, B., Steven, B., Margret, N., Ronald, N., Emmanuel, L., Tadeo, N., Namagembe, I., Kasangaki, A., \& Cecily, B. (2016). Prevalence and Factors Associated with Low Birth Weight among Teenage Mothers in New Mulago Hospital: A cross sectional Study. Journal of Health Science (El Monte), 4:192-199.

Mahande, M. J. \& Obure, J. (2016). Effect of Interpregnancy Interval on Adverse Pregnancy Outcomes in Northern Tanzania: A registry-based retrospective cohort study. BMC Pregnancy and Childbirth, 16(140), 0929-0950. https://doi.org/10.1186/s12884-0160929-5.

Maznah, D., Nazar, A., Oche, M., \& Norlaili, A. (2016). Risk factors for low birth weight in Nigeria: evidence from the 2013 Nigeria Demographic and Health Survey. Global Health Action, 9(1), 1-5.

Monjezi, M., Rostami, A., Moradi, M \& Cheraghian, B. (2014). Survey of the Relationship between Mother's Chronic Diseases and Low Birth Weight in Infants, Ahvaz, South of Iran. Jundishapur Journal Chronic Disease Care,6(2), e38259. https://doi.org/doi:10.17795/JJCDC-38259

Muchemi, O.M., Echoka, E., \& Makokha. A. (2015). Factors Associated with Low Birth Weight among Neonates Born at Olkalou District Hospital, Central Region, Kenya. Pan African Medical Journal, 20(1), 108. https://doi.org/doi:10.11604/pamj.2015.20.108.4831

Mukhtar-Yola, M., \& Iliyasu, Z. (2007). A Review of Neonatal Morbidity and Mortality in Aminu Kano Teaching Hospital, Northern Nigeria. Tropical doctor, 37(3), 130-132. https://doi.org/10.1258\%2F004947507781524683

Mulatu, H., Zepre, K., \& Hailemicael, M. (2016). Magnitude and Factors Associated with Low Birth Weight among Newborn in Selected Public Hospitals of Addis Ababa, Ethiopia. Global Journal of Medical Research,17(5-K).

Ochoga, Marthao \& Abah, Rose \& Idoko, Ame \& Dabit, J \& Ebonyi, Augustine \& Okpe, E. (2018). Pattern of Diseases and Outcomes of Neonatal Admission in Benue State University Teaching Hospital, Makurdi, Nigeria. Journal of Biomedical Research and Clinical Practice, 1. 74-80. https://doi.org/10.46912/jbrcp.37.

Oladeinde, H. B., Oladeinde, O. B., Omoregie, R., \& Onifade, A. A. (2015). Prevalence and Determinants of Low Birth Weight: The situation in a traditional birth home in Benin City, Nigeria. African Health Sciences, 15(4), 1123-1129. https://doi.org/10.4314/ahs.v15i4.10

Olaniyi, A.A.O., \& Ncama, B.P. (2019). Causes and Prevention of Newborn Deaths in Nigeria: Narrative literature review. Journal of Nursing and Health Sciences, 8(4), 19.

Olusanya, B.O., \& Ofovwe, G.E. (2010). Predictors of Preterm Births and Low Birth Weight in an Inner-city Hospital in Sub-Saharan Africa. Maternal and Child Health Journal, 14(6), 978-986. https://doi.org/10.1007/s10995-009-0528-4 
ISSN: 2689-9418

Volume 4, Issue 3, 2021 (pp. 121-138)

Project Concern International \& US Agency for International Development. (2015). Nigeria: Profile of preterm and low birth weight prevention and care. Retrieved from https://reliefweb.int/report/nigeria/nigeria-profile-preterm-and-low-birth-weightprevention-and-care

Siza, J. E. (2008). Risk Factors Associated with Low Birth Weight of Neonates Among Pregnant Women Attending a Referral Hospital in Northern Tanzania. Tanzania Journal of Health Research, 10(1), 1-8.

Takai, I.U., Bukar, M., \& Audu, B.M. (2014). A Prospective Study of Maternal Risk Factors for Low Birth Weight Babies in Maiduguri, North-Eastern Nigeria. Nigerian Journal of Basic and Clinical Sciences 11(2), 89-98.

Teklehaimot, N., Hailu, T., \& Assefa, H. (2014). Prevalence and Factors Associated with Low Birth Weight in Axum and Laelay Maichew Districts, North Ethiopia: A Comparative Cross-Sectional Study. International Journal of Nutrition and Food Sciences, 3(6): 560-566.

Tsimbos, C., \& Verropoulou, G. (2011). Demographic and Socioeconomic Determinants of Low Birth Weight and Preterm Births among Natives and Immigrants in Greece: An analysis using nationwide vital registration micro-data. Journal of Biosocial Science, 43(3), 271-283. https://doi.org/10.1017/S0021932010000726

Ugboma, H.A.A., \& Onyearugha, C.N. (2013). Low birthweight delivery: Prevalence and Associated Factors as seen at a Tertiary Health Facility. Nigerian Journal of Clinical Practice, 16(2), 184-187.

Wendt, A., Gibbs, C. M., Peters, S., \& Hogue, C. J. (2012). Impact of Increasing

Interpregnancy Interval on Maternal and Infant Health. Paediatric Perinatal Epidemiology, 26(1), 239-258. doi:10.1111/j.1365-3016.2012.01285.x

World Health Organization. (2014). Global Nutrition Targets 2025: Low Birth Weight Policy Brief. https://apps.who.int/iris/bitstream/handle/10665/149020/WHO_NMH_NHD_14

Yi, S., Han, Y., \& Ohrr, H. (2013). Anemia before Pregnancy and Risk of Preterm Birth, Low Birth Weight and Small-for-gestational-age Birth in Korean Women. European Journal of Clinical Nutrition, 67(4), 337-342. https://doi.org/10.1038/ejen.2013.12

Zeleke, B. M., Zelalem, M., \& Mohammed, N. (2012). Incidence and Correlates of Low Birth Weight at a Referral Hospital in Northwest Ethiopia. Pan African Medical Journal, 12(1).

Zenebe, K., Awoke, T., \& Birhan, N. (2014). Low Birth Weight \& Associated Factors among Newborns in Gondar Town, North West Ethiopia: Institutional Based Cross-Sectional Study. Indo Global Journal of Pharmaceutical Sciences, 4,74-80. 
African Journal of Health, Nursing and Midwifery

ISSN: 2689-9418

Volume 4, Issue 3, 2021 (pp. 121-138)

www.abjournals.org

\section{APPENDIX}

\section{BABCOCK UNIVERSITY}

HEALTH RESEARCH ETHICS COMMITTEE

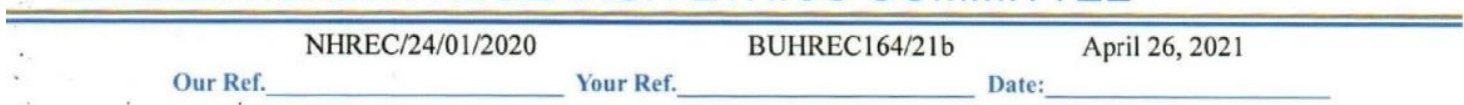

NAME OF PRINCIPAL INVESTIGATOR: ADEOSUN LYDIA T.

TITLE OF STUDY： FACTORS ASSOCIATED WITH LOW BIRTH WEIGHT BABIES DELIVERED IN SELECTED HEALTH FACILITIES IN ABUJA MUNICIPAL AREA COUNCIL, FCT, NIGERIA

RESEARCH LOCATION: ABUJA, NIGERIA. NOTIFICATION FOR ETHICAL APPROVAL

Babcock University Health Research Ethics Committee has approved your research proposal and other related materials after the necessary reviews and corrections.

The National code for Health Research Ethics requires that you comply with all institutional guidelines, rules and regulations. All forms and questionnaire must carry the assigned BUHREC number. No changes are permitted in the research without prior approval by the Committee.

Please, note that the Committee will monitor the research study. All data collection must be completed within twelve calendar months (One year), from the date stated on this approval.

You are expected to give a progress report of the investigation and submit a final copy of the research to the Committee.

This approval is with effect from March 31, 2021. This in response to your request for modification of title dated April 26, 2021.

Thank you.

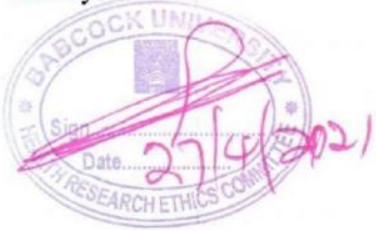

Professor S. O. Fapohunda

Chairman, Babcock University Health Research Ethics Committee 09133507122 